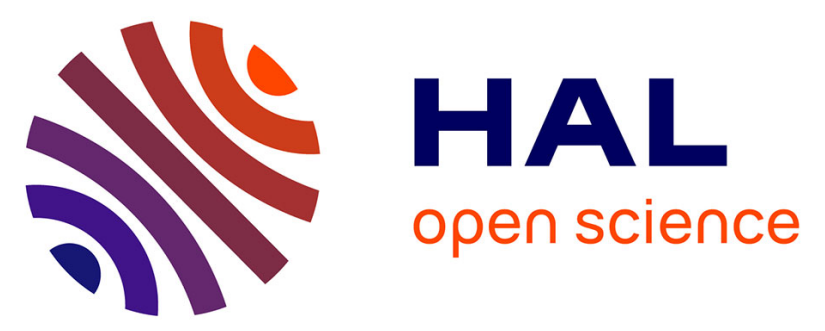

\title{
Chemical composition, antibacterial, antioxidant and tyrosinase inhibitory activities of glycosides from aerial parts of Eryngium tricuspidatum L.
}

Abbes Benmerache, Abdulmagid Alabdul Magid, Djemaa Berrehal, Ahmed Kabouche, Laurence Voutquenne-Nazabadioko, Souhila Messaili, Amin Abedini, Dominique Harakat, Zahia Kabouche

\section{To cite this version:}

Abbes Benmerache, Abdulmagid Alabdul Magid, Djemaa Berrehal, Ahmed Kabouche, Laurence Voutquenne-Nazabadioko, et al.. Chemical composition, antibacterial, antioxidant and tyrosinase inhibitory activities of glycosides from aerial parts of Eryngium tricuspidatum L.. Phytochemistry Letters, 2016, 18, pp.23 - 28. 10.1016/j.phytol.2016.08.018 . hal-01834066

\section{HAL Id: hal-01834066 \\ https://hal.univ-reims.fr/hal-01834066}

Submitted on 4 Nov 2021

HAL is a multi-disciplinary open access archive for the deposit and dissemination of scientific research documents, whether they are published or not. The documents may come from teaching and research institutions in France or abroad, or from public or private research centers.
L'archive ouverte pluridisciplinaire HAL, est destinée au dépôt et à la diffusion de documents scientifiques de niveau recherche, publiés ou non, émanant des établissements d'enseignement et de recherche français ou étrangers, des laboratoires publics ou privés. 


\title{
Chemical composition, antibacterial, antioxidant and tyrosinase inhibitory activities of glycosides from aerial parts of Eryngium tricuspidatum $\mathbf{L}$.
}

\author{
Abbes Benmerache ${ }^{\mathrm{a}}$, Abdulmagid Alabdul Magid ${ }^{\mathrm{b}, *}$, Djemaa Berrehal ${ }^{\mathrm{a}}$, Ahmed Kabouche ${ }^{\mathrm{a}}$, Laurence

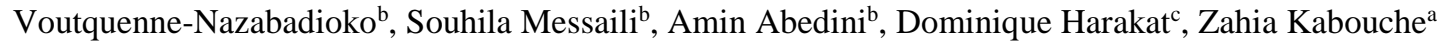 \\ ${ }^{a}$ Université des frères Mentouri-Constantine, Département de chimie, Laboratoire d'Obtention des Substances \\ Thérapeutiques (LOST), Campus Chaabet-Ersas, 25000 Constantine, Algeria \\ ${ }^{b}$ ICMR-UMR CNRS 7312, Groupe Isolement et Structure, Campus Sciences, Bât. 18, BP 1039, 51687 Reims \\ Cedex 2, France \\ ${ }^{c}$ Service Commun d'Analyses, ICMR-UMR CNRS 7312, Bât. 18 B.P.1039, 51687 Reims Cedex 2, France
}

* Corresponding author. Tel.: +33-3-26-91-82-08; fax: +33-3-26-91-35-96. E-mail address: abdulmagid.alabdulmagid@univ-reims.fr (A. Alabdul Magid)

\begin{abstract}
.
Two new phenolic glucosides, together with six known compounds, were isolated from the aerial part of Eryngium tricuspidatum L. (Apiaceae). The structures of the new compounds were established as 2-hydroxy3,5-dimethyl-acetophenon-4-O- $\beta$-D-glucopyranoside (1) and 2,3-dimethyl-4-hydroxymethylphenyl-1hydroxymethyl- $O-\beta$-D-glucopyranoside (2) on the basis of detailed spectroscopic data including MS, $1 \mathrm{D}$, and 2D NMR. The antibacterial, tyrosinase inhibitory and DPPH radical scavenging activities of hydromethanolic extract, fractions, and the eight isolated compounds were evaluated. The antibacterial assay showed a moderate activity for magnolioside (4) against Staphylococcus aureus CIP 53.154. Compound 7 (quercetin 3-O- $\beta$-Dglucopyranosyl-( $1 \rightarrow 6)-O$ - $\beta$-D-galactopyranoside) had moderate DPPH radical scavenging activity whereas compounds $\mathbf{2}$ exhibited good inhibitory effect against mushroom tyrosinase.
\end{abstract}

Keywords: Eryngium tricuspidatum, Apiaceae, antibacterial activity, antioxidant activity tyrosinase inhibitory activity.

\section{Introduction}

Eryngium tricuspidatum L. is a species belonging to the large family of Apiaceae, comprising more than 3000 species. Eryngium species is the largest genus with, approximately 250 species, distributed worldwide, mainly in Eurasia, North of Africa and South America (Merghache et al., 2014). About 7 species can be found in Algeria (Quezel and Santa, 1963). Plants of this genus are known for their rich content in secondary metabolites. Indeed, numerous studies undertaken on this genus have revealed presence of flavonoids (Khalfallah et al., 2014), saponins (Erdem et al., 2015), polyacetylene (Ayoub et al., 2006) and monoterpene glycosides (Nacef et al., 2008). Antiinflammatory (Kupeli et al., 2006), cytotoxic (Yurdakok and Baydan, 2013), antioxidant (Le Claire et al., 2005), antimicrobial (Ndip et al., 2007), and antidiabetic (Celik et al., 2011) activities have been reported from Eryngium species. In folk medicine, various Eryngium species are used against inflammatory disorders or as antitussive, diuretic, appetizer, stimulant, and aphrodisiac (Suciu and Pârvu, 2012).

Eryngium tricuspidatum L. grows in North Africa, Spain, Sardinia and Sicily (Merghache et al., 2014, Tahri et al., 2011). The decoction of its roots is effective against poisoning and constipation (Bamm and Douira, 2002). The chemical composition and the antibacterial, antifungal and antioxidant activities of the aerial parts essential oil of E. tricuspidatum have been reported recently (Merghache et al, 2014). The essential oil showed significant antibacterial and antifungal property against $S$. aureus, E. faecalis, P. aeruginosa (MIC $9 \mu \mathrm{g} / \mathrm{mL}$ ) and C. albicans (MIC $4.6 \mu \mathrm{g} / \mathrm{mL}$ ) and moderate DPPH radical-scavenging activity and ferric reducing-antioxidant power. In continuation of our phytochemical and bioactivity studies on the Algerian plants, herein we reported the isolation, structural identification and bioactivities (antibacterial, antioxidant, and tyrosinase inhibitory) of extracts and compounds from the aerial parts of E. tricuspidatum. 


\section{Results and discussion}

The $50 \% \mathrm{MeOH}$ extract afforded two new phenolic glycosides (1) and (2) as well as six known compounds, benzyl-1- $O$ - $\beta$-Dglucopyranoside (3) (Wen et al., 2012), magnolioside (4) (Tanja et al., 2005), asysgangoside (5) (Kanchanapoom and Ruchirawat, 2007), citroside B (6) (Yang et al., $2012)$, quercetin 3-O- $\beta$-D-glucopyranosyl-( $1 \rightarrow 6)$ $O$ - $\beta$-D-galactopyranoside (7) (Nawwar et al., 1989), and kaempferol 3-O- $\beta$-D-glucopyranosyl$(1 \rightarrow 6)-O-\beta$-D-galactopyranoside $(\mathbf{8})$ (Hiller et al., 1980).

Compound 1 was obtained as a colorless amorphous solid. The negative HR-ESI-MS spectrum showed a molecular ion peak at $\mathrm{m} / \mathrm{z}$ 341.1241 [M-H] $^{-}$and the molecular formula was deduced as $\mathrm{C}_{16} \mathrm{H}_{22} \mathrm{O}_{8}$ (calcd 341.1236). The UV spectrum revealed absorption bands at 268 and $326 \mathrm{~nm}$. Analysis of the ${ }^{1} \mathrm{H}$ and ${ }^{13} \mathrm{C}$ NMR spectra of 1 revealed the presence of an anomeric proton at $\delta_{\mathrm{H}} 4.75(\mathrm{~d}, J=7.7 \mathrm{~Hz})$ correlated in the HSQC spectrum with an anomeric carbon at $\delta_{\mathrm{C}} 103.9$ (Table 1). The sugar unit was assigned as a $\beta$-Dglucopyranosyl unit according to the COSY, HSQC, and HMBC correlations as well as the coupling constant values of all oxymethine protons (Yashiro et al., 2001) (Table 1). The relative configuration of $\beta$-D-glucopyranosyl moiety was further confirmed by analysis of the ROESY correlations [22] from the $\alpha$-axial protons $\mathrm{H}-1 / \mathrm{H}-3$ and $\mathrm{H}-1 / \mathrm{H}-5$. The ${ }^{1} \mathrm{H}$ NMR and ${ }^{13} \mathrm{C}$ NMR spectra of 1 (Table 1) revealed also the presence of an acetyl group at $\delta_{\mathrm{H}} 2.60(3 \mathrm{H}, \mathrm{s})$, one aromatic proton at $\delta_{\mathrm{H}} 7.60(1 \mathrm{H}, \mathrm{s})$, and two methyl signals at $\delta_{\mathrm{H}} 2.30(3 \mathrm{H}, \mathrm{s})$ and $2.35(3 \mathrm{H}, \mathrm{s})$. The signal at $\delta_{\mathrm{H}}$ 2.60 correlate in the HSQC spectrum with carbon at $\delta_{\mathrm{C}} 25.3$, and in the HMBC spectrum with carbon at $\delta_{\mathrm{C}} 115.0$ and the carbonyl carbon at $\delta_{\mathrm{C}} 205.0$. Five signals of quaternary carbons were observed at $\delta_{\mathrm{C}} 115.0,120.0,122.0,159.9$ and 160.0 , the two at $\delta_{C} 160.0$ and 159.9 were consistent with the aromatic carbons bearing a hydroxyl substituent. The signal at $\delta_{\mathrm{C}} 129.7$ showed correlation with the singlet at $\delta_{\mathrm{H}} 7.60$ in the HSQC experiment. The anomeric carbon at $\delta_{\mathrm{C}} 103.9$ exhibited correlation with the quaternary carbon at $\delta_{C} 159.9$ in the HMBC experiment, revealing the position of the glucose moiety on the aromatic ring. The methyl signals at $\delta_{\mathrm{C}} 8.4$ and 15.8 correlated in the HSQC experiment with their corresponding protons at $\delta_{\mathrm{H}}$ 2.30 and 2.35. The HMBC spectra showed correlations between the protons at $\delta_{\mathrm{H}} 2.30$ and carbons at $\delta_{\mathrm{C}} 120.0,160.0$, and 159.9, and between the protons at $\delta_{\mathrm{H}} 2.35$ and carbons at $\delta_{\mathrm{C}}$ 122.0, 129.7 and 159.9 (Fig. 2), assigning the positions of the two methyl groups. The aromatic proton $\left(\delta_{\mathrm{H}}\right.$ 7.60) correlated in the HMBC spectra with carbons at $\delta_{\mathrm{C}}$ 205.0, 160.0, 159.9, and 15.8. Further interpretation of 2D NMR especially HMBC data (Fig. 2) established that compound $\mathbf{1}$ was an acetophenone derivative substituted by two methyls and two hydroxyl groups (Kuang et al., 2008, Vendetti et al., 2014) (Fig. 1). To exclude a different position of the substituents $\left(\mathrm{Ar}-\mathrm{CH}_{3}\right.$ and Ar-CO- $-\mathrm{CH}_{3}$ ), a ROESY experiment was performed and showed rOe correlations between the aromatic proton $\mathrm{H}-6^{\prime}$ and the methyl protons $\mathrm{H}_{3}-2$ and $\mathrm{H}_{3}-8^{\prime}$ and between the anomeric proton $\mathrm{H}-1^{\prime \prime}$ and the two methyl protons $\mathrm{H}_{3}-3^{\prime}$ and $\mathrm{H}_{3}-8^{\prime}$. These evidences were consistent with the structure of $\mathbf{1}$ as 2-hydroxy-3,5-dimethyl-acetophenon-4-O$\beta$-D-glucopyranoside

Compound 2 was obtained as a colorless solid. The $[\mathrm{M}+\mathrm{Na}]^{+}$ion at $\mathrm{m} / \mathrm{z} 351.1412$ (calcd for $\mathrm{C}_{16} \mathrm{H}_{24} \mathrm{O}_{7} \mathrm{Na}$; 351.1420) in the HR-ESI-MS spectra was consistent with the molecular formula $\mathrm{C}_{16} \mathrm{H}_{24} \mathrm{O}_{7}$. The UV spectrum revealed absorption band at $276 \mathrm{~nm}$. The ${ }^{1} \mathrm{H}$ and ${ }^{13} \mathrm{C}$ NMR spectra of 2 (Table 1) showed the presence of a $\beta$-Dglucopyranosyl moiety from the anomeric signals at $\delta_{\mathrm{C}} 101.6$ and $\delta_{\mathrm{H}} 4.32(\mathrm{~d}, J=7.7 \mathrm{~Hz})$. The ${ }^{13} \mathrm{C}$ NMR spectrum exhibited 16 distinct carbon resonances, 6 of which were assigned for the $\beta$-Dglucopyranosyl unit. The ${ }^{1} \mathrm{H}$ NMR spectrum of the aglycone of $\mathbf{2}$ exhibited two $\mathrm{AB}$ type aromatic protons at $\delta_{\mathrm{H}} 7.25$ and 7.18 (each $1 \mathrm{H}, \mathrm{d}, J=7.8$ $\mathrm{Hz}$ ), two methyl groups at $\delta_{\mathrm{H}} 2.29$ and 2.33 connected to an aromatic ring, and two pairs of methylene protons bearing oxygen functions $\left[\delta_{\mathrm{H}}\right.$ 4.65 (2H, s), 4.69 and 4.99 (each $1 \mathrm{H}, \mathrm{d}, J=11.5$ )] (Table 1). Analysis of the ${ }^{1} \mathrm{H}$ and ${ }^{13} \mathrm{C}$ NMR, HSQC and HMBC spectra allowed assignment to $\mathbf{2}$ of two methyls [ $\delta_{\mathrm{C}} 13.5\left(\mathrm{CH}_{3}-9\right)$ and $13.9\left(\mathrm{CH}_{3}-8\right)$ ], two hydroxymethyls [ $\delta_{\mathrm{C}} 62.7(\mathrm{C}-10)$ and $69.5(\mathrm{C}-7)$ ], two methines [126.7 (C-6) and 124.8 (C-5)] and four quaternary carbons [134.6 (C-1), 137.5 (C-2), 138.7 (C-3) and 134.6 (C-4)] indicating the presence of a 1,2,3,4-tetrasubstituted aromatic ring. From these observation, compound $\mathbf{2}$ was similar to 2,3,4-trimethylphenylalcohol- $O$ - $\beta$-Dglucopyranoside, previously isolated from Prangos tschimganica [23]. The only difference 
was the presence of a hydroxymethyl group in $\mathbf{2}$, instead a methyl group. The HMBC spectrum showed correlations between $\mathrm{H}_{2}-10\left(\delta_{\mathrm{H}} 4.65\right)$ and $\mathrm{C}-3, \mathrm{C}-4$, and $\mathrm{C}-5$ which allowed assignment of $\mathrm{CH}_{2}-10$ in position $\mathrm{C}-4$ whereas HMBC correlations between $\mathrm{H}_{2}-7\left(\delta_{\mathrm{H}} 4.69\right.$ and 4.99) and C-1, C-2, and C-6 placed C-7 in position C-1 (Fig. 2). The HMBC correlations between $\mathrm{H}_{3}-8$ and $\mathrm{C}-1$, C-2 and C-3 allowed assignment of $\mathrm{CH}_{3}-8$ in position $\mathrm{C}-2$ whereas HMBC correlations between $\mathrm{H}_{3}-9$ and $\mathrm{C}-2, \mathrm{C}-3$ and $\mathrm{C}-4$ placed the $\mathrm{CH}_{3}-9$ in<smiles>CC(=O)c1cc(C)c(OC2OC(CO)[C@@H](O)[C@H](O)[C@H]2O)c(C)c1O</smiles>

position $\mathrm{C}-3$. In addition, an $\mathrm{HMBC}$ correlation observed between the anomeric proton $\mathrm{H}-1^{\prime}$ and $\mathrm{C}$ $7\left(\delta_{\mathrm{c}} 69.5\right)$ indicated that the glucopyranosyl unit was linked at C-7. These assignments were supported by the observation of the rOe effects between H-6/H-7, H-7/H-8, H-8/H-9, H-9/H-10, $\mathrm{H}-10 / \mathrm{H}-5$ and $\mathrm{H}-1^{\prime} / \mathrm{H}-7$ in the ROESY spectrum. Therefore, compound $\mathbf{2}$ was determined to be 2,3dimethyl-4-hydroxymethyl-1-

hydroxymethylphenyl-O- $\beta$-D-glucopyranoside.

Figure 1: Chemical structure of compounds $\mathbf{1}$ and $\mathbf{2}$ isolated from E. tricuspidatum.

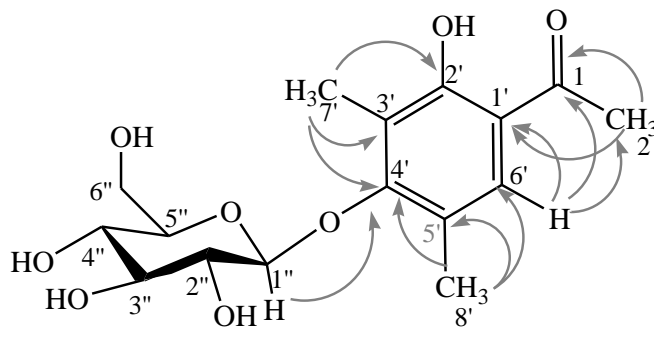

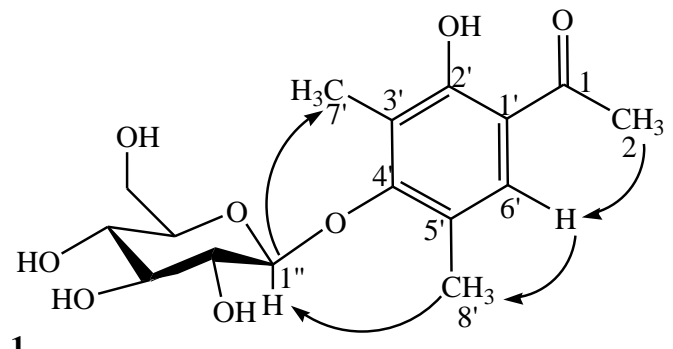

1<smiles>Cc1c(CO)ccc(COC2OC(CO)[C@@H](O)C(O)[C@H]2O)c1C</smiles>

2

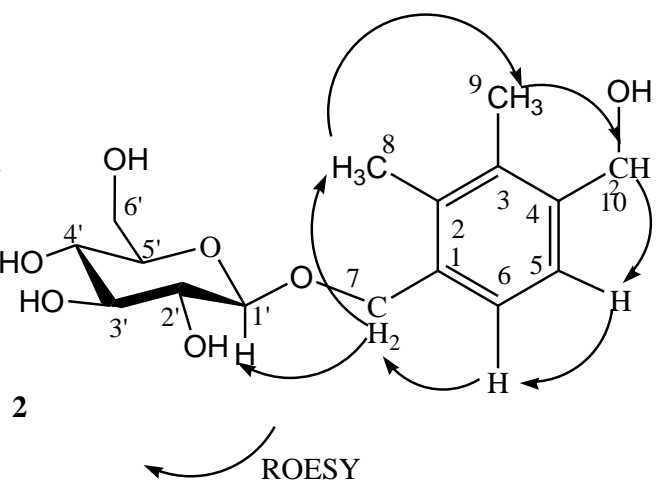

HMBC

Figure 2: Key HMBC and ROESY relationships of compounds $\mathbf{1}$ and $\mathbf{2}$ 
Table 1. ${ }^{1} \mathrm{H}$ NMR and ${ }^{13} \mathrm{C}$ NMR data $\mathrm{CD}_{3} \mathrm{OD}$ for compounds 1 and 2.

\begin{tabular}{|c|c|c|c|c|c|c|c|}
\hline & \multicolumn{3}{|c|}{1} & \multicolumn{4}{|c|}{2} \\
\hline & $\delta_{\mathrm{H}} \mathrm{m}(J$ in $\mathrm{Hz})$ & $\delta_{\mathrm{C}}$ & $\mathrm{HMBC}$ ( $\mathrm{H}$ to $\mathrm{C})$ & & $\delta_{\mathrm{H}} \mathrm{m}(J$ in $\mathrm{Hz})$ & $\delta_{\mathrm{C}}$ & $\mathrm{HMBC}$ ( $\mathrm{H}$ to $\mathrm{C})$ \\
\hline 1 & - & 205.0 & - & 1 & - & 134.6 & - \\
\hline 2 & $2.60 \mathrm{~s}$ & 25.3 & $\mathrm{C}-1, \mathrm{C}-1^{\prime}$ & 2 & - & 137.5 & - \\
\hline $\mathbf{1}^{\prime}$ & - & 115.0 & - & 3 & - & 138.7 & - \\
\hline $2^{\prime}$ & - & 160.0 & - & 4 & - & 134.6 & - \\
\hline $3^{\prime}$ & - & 120.0 & & 5 & $7.18 \mathrm{~d}(7.8)$ & 124.8 & $\mathrm{C}-3, \mathrm{C}-4$ \\
\hline $4^{\prime}$ & - & 159.9 & & 6 & $7.25 \mathrm{~d}(7.8)$ & 126.7 & $\mathrm{C}-1$ \\
\hline $5^{\prime}$ & - & 122.0 & & 7 & $4.69 \mathrm{~d}(11.5)$ & 69.5 & C-1, C-2, C-6, C-1' \\
\hline $6^{\prime}$ & $7.60 \mathrm{~s}$ & 129.7 & C-1, C-2', C-8' & & $4.99 \mathrm{~d}(11.5)$ & & \\
\hline $7^{\prime}$ & $2.30 \mathrm{~s}$ & 8.4 & $\mathrm{C}-2^{\prime}, \mathrm{C}-3^{\prime}, \mathrm{C}-4^{\prime}$ & 8 & $2.33 \mathrm{~s}$ & 13.9 & $\mathrm{C}-1, \mathrm{C}-2, \mathrm{C}-3$ \\
\hline \multirow[t]{2}{*}{$8^{\prime}$} & $2.35 \mathrm{~s}$ & 15.8 & $\mathrm{C}-4^{\prime}, \mathrm{C}-5^{\prime}, \mathrm{C}-6^{\prime}$ & 9 & $2.29 \mathrm{~s}$ & 13.5 & $\mathrm{C}-2, \mathrm{C}-3, \mathrm{C}-4$ \\
\hline & & & & 10 & $4.65 \mathrm{~s}$ & 62.7 & $C-3, C-4, C-5$ \\
\hline glc & & & & glc & & & \\
\hline $\mathbf{1}^{\prime \prime}$ & $4.75 \mathrm{~d}(7.7)$ & 103.9 & C- $4^{\prime}$ & $\mathbf{1}^{\prime}$ & $4.32 \mathrm{~d}(7.7)$ & 101.6 & $\mathrm{C}-7, \mathrm{C}-3^{\prime}$ \\
\hline $2^{\prime \prime}$ & 3.54 t (7.8) & 74.3 & $\mathrm{C}-1^{\prime \prime}, \mathrm{C}-2^{\prime \prime}$ & $2^{\prime}$ & $3.26 \mathrm{t}(7.8)$ & 73.7 & $\mathrm{C}-1^{\prime}$ \\
\hline $3^{\prime \prime}$ & $3.45 \mathrm{t}(7.9)$ & 76.5 & C-2", C-4" & $3^{\prime}$ & $3.33 \mathrm{t}(7.9)$ & 76.8 & $\mathrm{C}-2^{\prime}$ \\
\hline $4^{\prime \prime}$ & $3.40 \mathrm{t}(7.9)$ & 70.1 & $\mathrm{C}-3^{\prime \prime}$ & $4^{\prime}$ & $3.29 \mathrm{t}(7.9)$ & 70.4 & $\mathrm{C}-5^{\prime}$ \\
\hline $5^{\prime \prime}$ & $3.17 \mathrm{~m}$ & 76.7 & C-4" & $5^{\prime}$ & $3.80 \mathrm{~m}$ & 76.6 & $\mathrm{C}-4^{\prime}$ \\
\hline \multirow[t]{2}{*}{$6^{\prime \prime}$} & $3.67 \mathrm{dd}(11.8,5.7)$ & 61.3 & C-5" & $6^{\prime}$ & $3.71 \mathrm{dd}(11.8,5.7)$ & 61.6 & $\mathrm{C}-5^{\prime}$ \\
\hline & $3.79 \mathrm{dd}(11.80,2.1)$ & & $\mathrm{C}-5^{\prime \prime}$ & & $3.71 \mathrm{dd}(11.8,2.1)$ & & \\
\hline
\end{tabular}

Several biological activities of Eryngium species e.g., anti-inflammatory, antioxidant, and antimicrobial, were reported. Moreover, the aerial parts essential oil showed antibacterial and antifungal and DPPH radical-scavenging activities. Thus, the hydromethanolic extract, fractions I-V, and compounds 1-8 were tested for their antibacterial, antioxidant and tyrosinase inhibitory activities.

The hydromethanolic extract and fractions I-V were initially tested for their antibacterial capacity against Staphylococus aureus CIP 53.154 by using TLC bioautography method (Table 2). The results showed a high activity for the fraction I and a milder activity for the fractions IV and $\mathrm{V}$ comparable with the reference gentamicin. Despite these positive results for three fractions, the extract did not show anti-staphylococcal activity. It could be due to the presence of a small percentage of antibacterial compounds in $50 \% \mathrm{MeOH}$ extract. Subsequently, the test was repeated for eight compounds isolated from fractions I, II and III, and only the compound $\mathbf{4}$, obtained from the fraction I, was moderately active. In our opinion, it is possible that the antimicrobial activity of fraction $I$ is a synergistic effect of the major and minor constituents, present in the fraction.
Table 2. Biological activities of 50\% $\mathrm{MeOH}$ extract, fractions $\mathrm{I}-\mathrm{V}$, and compounds 1-8.

\begin{tabular}{|c|c|c|c|}
\hline & $\begin{array}{l}\text { Antibacterial } \\
\text { activity against } \\
\text { S.aureus } \\
\text { inhibition zone } \\
\text { at } 50 \mu \mathrm{g} \text { (in } \\
\mathrm{cm} \text { ) }\end{array}$ & $\begin{array}{c}\mathrm{DPPH} \\
\text { radical } \\
\text { scavenging } \\
\text { activity } \\
\mathrm{IC}_{50} \\
(\mu \mathrm{g} / \mathrm{mL}) \\
\end{array}$ & $\begin{array}{c}\text { Mushroom } \\
\text { tyrosinase } \\
\text { inhibition } \\
\mathrm{IC}_{50} \\
(\mu \mathrm{g} / \mathrm{mL})\end{array}$ \\
\hline $\begin{array}{l}50 \% \mathrm{MeOH} \\
\text { extract }\end{array}$ & na & $180 \pm 10$ & 1900 \\
\hline Fraction I & 1.5 & nd & nd \\
\hline Fraction II & na & 170 & 1920 \\
\hline Fraction III & na & 160 & 1850 \\
\hline Fraction IV & 0.5 & nd & nd \\
\hline Fraction V & 0.5 & nd & nd \\
\hline 1 & na & nd & 1950 \\
\hline 2 & na & nd & 80.0 \\
\hline 3 & na & nd & nd \\
\hline 4 & 0.5 & nd & nd \\
\hline 5 & na & nd & nd \\
\hline 6 & na & nd & nd \\
\hline 7 & na & 20.0 & nd \\
\hline 8 & na & 150 & nd \\
\hline Gentamicin $^{\mathrm{a}}$ & 1.0 & & \\
\hline $\begin{array}{l}\text { Ascorbic } \\
\text { acid }^{\mathrm{a}}\end{array}$ & & 6.3 & \\
\hline Kojic acid $^{\mathrm{a}}$ & & & 20.0 \\
\hline \multicolumn{4}{|c|}{$\begin{array}{l}\text { na : not actif at } 50 \mu \mathrm{g} \\
\text { nd }: 50 \% \text { inhibition not achieved at the concentration of } \\
200 \mu \mathrm{g} / \mathrm{mL} \text {. } \\
\text { a'Used as a positive control. } \\
\text { The DPPH radical scavenging activity of } 50 \% \\
\text { MeOH extract, fractions I-V, and compounds } \mathbf{1 - 8} \\
\text { was measured and their } \mathrm{IC}_{50} \text { are listed in Table } 2 \text {. } \\
\text { In this assay, antioxidants were able to reduce the } \\
\text { stable radical DPPH to the yellow-colored } \\
\text { diphenyl-picrylhydrazine. }\end{array}$} \\
\hline
\end{tabular}


extract and fractions I, II and III showed low DPPH radical scavenging activity ( $\mathrm{IC}_{50}$ 160-180 $\mu \mathrm{g} / \mathrm{mL})$. Only compound 7 exhibited moderate scavenging activity on DPPH radical with $\mathrm{IC}_{50}$ of $20 \mu \mathrm{g} / \mathrm{mL}$, compared with the reference ascorbic acid $\left(\mathrm{IC}_{50} 6.3 \mu \mathrm{g} / \mathrm{mL}\right)$. The seven other compounds showed low or no antiradical activity.

As initially stated, we measured the mushroom tyrosinase inhibitory effects of $50 \% \mathrm{MeOH}$ extract, fractions I-V and compounds 1-8, isolated from E. tricuspidatum. We found that the two new compounds ( $\mathbf{1}$ and $\mathbf{2}$ ) could reduce mushroom tyrosinase activity with dose-dependent trends (Table 2). Compound $\mathbf{2}$ exhibited good tyrosinase inhibitory effect ( $\mathrm{IC}_{50} 80 \mu \mathrm{g} / \mathrm{mL}$ ), compared to the reference kojic acid ( $\mathrm{IC}_{50} 20 \mu \mathrm{g} / \mathrm{mL}$ ).

In summary, two new phenolic glucosides, along with six known compounds, were isolated from the aerial parts of E. tricuspidatum. The antibacterial assay showed a high activity for the fraction I and a milder activity for compound $\mathbf{4}$. Compound 7 had moderate antioxidant abilities in DPPH scavenging activity. Compound $\mathbf{2}$ showed a good in vitro mushroom tyrosinase inhibitory activity, compared to kojic acid.

\section{Experimental}

\subsection{General experimental procedures}

The optical rotations were recorded on a PerkinElmer 341 Polarimeter. The UV spectra were obtained in methanol on a Shimadzu UV2450 spectrophotometer. 1D and 2D NMR spectra were recorded in $\mathrm{CD}_{3} \mathrm{OD}$ on a Bruker Avance DRX III $500 \mathrm{MHz}$ spectrometer $\left({ }^{1} \mathrm{H}\right.$ at $500 \mathrm{MHz}$ and ${ }^{13} \mathrm{C}$ at $125 \mathrm{MHz}$ ). 2D-NMR experiments were performed using standard Bruker microprograms. Chemical shifts $(\delta)$ are reported in ppm using the internal solvent resonances at $\delta_{\mathrm{H}} 3.33$ and $\delta_{\mathrm{C}} 47.6$ $\left(\mathrm{CD}_{3} \mathrm{OD}\right)$. HR-ESI-MS experiments were performed using a Micromass Q-TOF instrument, equipped with a pneumatically assisted electrospray ion source (Manchester, UK). Silica gel $60 \mathrm{~F}_{254}$ precoated aluminium plates $(0.2 \mathrm{~mm}$, Merck) were used for TLC analysis. The TLC and PTLC spots were visualized under UV light (254 and $366 \mathrm{~nm}$ ) followed by spraying with $50 \%$ $\mathrm{H}_{2} \mathrm{SO} 4$ and heating. All solvents were AR grade. Column chromatography was carried out on Kieselgel 60 (63-200 mesh) or LiChroprep RP-18 (40-63 $\mu \mathrm{m})$ Merck. High Performance Flash chromatography was performed on a Grace
Reveleris system equipped with dual UV and ELSD detection using Grace ${ }^{\circledR}$ cartridges (Silica gel or $\mathrm{RP}-\mathrm{C}_{18}$ ) and a flow rate of $30 \mathrm{~mL} / \mathrm{min}$. The chromatograms were monitored at 205, 225, 250, and $360 \mathrm{~nm}$. HPLC was performed on a Dionex apparatus equipped with an ASI-100 autosampler, an Ultimate 3000 pump, a diode array detector UVD 340S and a Chromeleon software. RP-C18

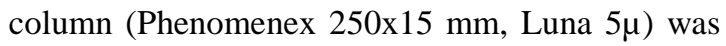
used for semi preparative HPLC with a binary gradient eluent $\left(\mathrm{H}_{2} \mathrm{O}(\mathrm{pH} 2.4\right.$ with TFA); MeCN) and a flow rate of $5 \mathrm{~mL} / \mathrm{min}$; the chromatogram was monitored at 205, 225, 250, and $350 \mathrm{~nm}$. Absorbance (A) values in the DPPH free radical scavenging and antityrosinase assay were read on a Fluostar omega microplate reader (BMG labtech).

\subsection{Plant material}

The aerial parts of E. tricuspidatum were collected in Mars 2013 from Constantine (North Eastern Algerian). A voucher specimen (Et.03.13) has been deposited in the Herbarium of the Department of Chemistry, Université des frères Mentouri-Constantine, and authenticated by Prof. Gérard De Belair (University of Annaba, Algeria).

\subsection{Extraction and isolation}

The dried aerial parts (1000 g) of E. tricuspidatum were macerated in $50 \% \mathrm{MeOH}(3 \times 5 \mathrm{~L}, 24 \mathrm{~h})$ at room temperature. After filtration and concentration under low pressure, $60 \mathrm{~g}$ of $\mathrm{MeOH}$ $50 \%$ extract was obtained. A part of the $50 \%$ $\mathrm{MeOH}$ extract (45 g) was subjected to Diaion HP20 resin column chromatography eluted with 25 , 50, 75, and $100 \% \mathrm{MeOH}$.

Fraction eluted with $50 \% \mathrm{MeOH}$ (5.2 g) was subjected to RP-C18 vacuum liquid chromatography (VLC) using a gradient of $\mathrm{MeOH}-\mathrm{H}_{2} \mathrm{O}(20,40,60,80$, and $100 \% \mathrm{MeOH})$ to give fractions I-V, successively. Fraction I ( $2 \mathrm{~g}$ ) was subjected to Flash chromatography over silica gel, eluted by a gradient system of $\mathrm{CHCl}_{3}-\mathrm{MeOH}$ $(0-30 \% \mathrm{MeOH})$, in $30 \mathrm{~min}$, to afford 14 fractions $\left(\mathrm{I}_{1}-\mathrm{I}_{14}\right)$. Fractions $\mathrm{I}_{5}$ and $\mathrm{I}_{7}$ corresponds to compounds 3 (4.4 mg) and 4 (16 mg), respectively. Fractions $I_{11}(32 \mathrm{mg})$ was purified by semi-prep HPLC (32 \% $\mathrm{MeCN})$ to afford compounds $5\left(\mathrm{R}_{\mathrm{t}} 9.57 \mathrm{~min}, 2.1 \mathrm{mg}\right)$ and $\mathbf{1}\left(\mathrm{R}_{\mathrm{t}}\right.$ $19.13 \mathrm{~min}, 1.8 \mathrm{mg})$. Fractions II-III (2.2 g) were subjected together to Flash chromatography, over silica gel, eluted by a gradient system of $\mathrm{CHCl}_{3}$ $\mathrm{MeOH}(0-40 \% \mathrm{MeOH})$, in $30 \mathrm{~min}$, to afford 19 
fractions [(II-III) $\left.)_{1-}(\mathrm{II}-\mathrm{III})_{19}\right]$. Fractions (II-III) $)_{15}$ (37 mg) was purified by semi-prep HPLC (25\% $\mathrm{MeCN})$ affording compounds $2\left(\mathrm{R}_{\mathrm{t}} 11.87 \mathrm{~min}, 2\right.$ $\mathrm{mg})$ and $6\left(\mathrm{R}_{\mathrm{t}} 15.19 \mathrm{~min}, 2.1 \mathrm{mg}\right)$. Fraction (IIIII $)_{17} \quad(180 \mathrm{mg})$ was subjected to Flash chromatography, over $\mathrm{RP}-\mathrm{C}_{18}$, eluted with $\mathrm{H}_{2} \mathrm{O}$ $\mathrm{MeOH}(5-45 \% \mathrm{MeOH})$ in $30 \mathrm{~min}$ and then purified by semi-prep HPLC (20\% MeCN) to yield compounds $7\left(\mathrm{R}_{\mathrm{t}} 9.06 \mathrm{~min}, 1.6 \mathrm{mg}\right)$ and 8 $\left(\mathrm{R}_{\mathrm{t}} 10.06 \mathrm{~min} 6.5 \mathrm{mg}\right)$.

\section{2-hydroxy-3,5-dimethyl-acetophenon-4- $O$ - $\beta$-D-} glucopyranoside (1)

Colorless amorphous powder. $[\alpha]_{\mathrm{D}}{ }^{20}-49$ (c 0.2 , $\mathrm{MeOH}) . \mathrm{UV}_{\max }(\mathrm{MeOH}) 268$ (2.7), $326(0.98) .{ }^{1} \mathrm{H}$ NMR and ${ }^{13} \mathrm{C}$ NMR $\left(\mathrm{CD}_{3} \mathrm{OD}\right)$, Table 1 . HR-ESIMS: $m / z 341.1236$ [M-H] $]^{-}$(calcd for $\mathrm{C}_{16} \mathrm{H}_{21} \mathrm{O}_{8}$ ).

\section{2,3-dimethyl-4-hydroxymethyl-1-}

hydroxymethylphenyl- $O$ - $\beta$-D-glucopyranoside (2)

Colorless amorphous powder. $[\alpha]_{\mathrm{D}}{ }^{20}-153.8$ (c 0.13, MeOH). $\mathrm{UV}_{\max }(\mathrm{MeOH}): 276(0.4) .{ }^{1} \mathrm{H}$ and ${ }^{13} \mathrm{C}$ NMR $\left(\mathrm{CD}_{3} \mathrm{OD}\right)$, Table 1. HR-ESI-MS: $\mathrm{m} / \mathrm{z}$ $351.1420[\mathrm{M}+\mathrm{Na}]^{+}\left(\right.$calcd for $\left.\mathrm{C}_{16} \mathrm{H}_{24} \mathrm{O}_{7} \mathrm{Na}\right)$.

3.4. Sugar analysis and determination of absolute configuration

A part of fractions I-III (100 mg each) was refluxed with TFA $2 \mathrm{~N}(15 \mathrm{~mL})$ for $4 \mathrm{~h}$. After filtration, the mixture was extracted with EtOAc (3 $\mathrm{x} 10 \mathrm{~mL}$ ) and the acid aq layer was evaporated. The residue was purified by prep. HPLC, on a Rezex ROA column with $\mathrm{H}_{2} \mathrm{SO}_{4} 2.5 \mathrm{mM}$, as solvent, to yield glucose and galactose. The monosaccharide fractions were then neutralized with $\mathrm{NaOH} 50 \mathrm{mM}$ and freeze-dried. The residues were solubilized in pyridine and soln. were filtrated and then evaporated. Glucose and galactose were dissolved in hexane-EtOH-TFA (50:50:1) by ultrasonication. The solutions were analyzed by chiral HPLC with a Chiralpak IC, using a mixture of hexane-EtOH-TFA (80:20:0.1), as solvent. By comparison with authentic D or $\mathrm{L}$ monosaccharide samples, the configurations were identified as D-glucose ( $R \mathrm{t} 19.32 \mathrm{~min}$ ) and Dgalactose (Rt $19.39 \mathrm{~min}$ )

3.5. Biological activities

3.5.1. Bioautography for antibacterial activity

This method is used mostly to identify the compounds responsible for the antibacterial activity in complex extracts. In this study, an immersion bioautography method was employed as a preliminary antibacterial evaluation (Abedini et al., 2013). An aliquot of extract/fraction/compound (2 $\mathrm{mg}$ ) was solubilized in $1 \mathrm{~mL}$ methanol. The resulting solutions $(25 \mu \mathrm{L})$ were spotted onto Merck $60 \mathrm{~F}_{254}$ pre-coated silica gel plates $(10 \times 10 \mathrm{~cm})$. Gentamicin $(50 \mu \mathrm{g})$ was also spotted on the plates as a positive control. The TLC plates were directly dried without migration and sterilized. The plates were then covered by Mueller-Hinton (MH) agar medium containing a Staphylococcus aureus 53.154 suspension $\left(10^{5}\right.$ bacteria/mL) in square Petri dishes. After incubation $24 \mathrm{~h}$ at $37{ }^{\circ} \mathrm{C}$, bacterial growth was revealed by a $2 \mathrm{mg} / \mathrm{mL}$ solution of thiazolyl blue tetrazolium bromide (MTT) and growth inhibition zones were measured. White stains indicate where reduction of MTT to the colored formazan did not take place due to the presence of extracts that inhibited bacterial growth.

3.5.2. Free radicals scavenging activity

The antioxidant activity of our target compound was measured in terms of hydrogen donating or radical scavenging ability using the stable DPPH method (Bendaikha et al., 2014). Briefly, $5 \mu \mathrm{L}$ of different concentrations of the samples (dissolved in DMSO) were added to $95 \mu \mathrm{L}$ of DPPH solution (158 $\mu \mathrm{M}$, dissolved in $\mathrm{EtOH} 50 \%$ ). The reaction proceeded for $30 \mathrm{~min}$ at $37{ }^{\circ} \mathrm{C}$ on a 96-well microplate. The absorbance was then read at $\lambda 515$ $\mathrm{nm}$. The percentage of inhibition was calculated using the following equation: $\%$ inhibition $\left[\left(\mathrm{Ab}_{\text {control }}-\mathrm{A} \mathrm{b}_{\text {sample }}\right) / \mathrm{Ab}_{\text {control }}\right] \times 100 . \mathrm{DPPH}$ solution in $\mathrm{EtOH} 50 \%$ was used as a control. The curve of the $\%$ scavenging activity against the concentration of sample was prepared by MSExcel based program to obtain the $\mathrm{IC}_{50}$ (concentration required to obtain a $50 \%$ antioxidant effect). All the tests were conducted in triplicate. Ascorbic acid was used as a positive control agent.

\subsection{Tyrosinase enzyme assay}

Tyrosinase activity inhibition was determined spectrophotometrically according to the method described previously (Bendaikha et al., 2014). Different concentrations of test compounds were prepared in $10 \%$ DMSO in aqueous solution and $100 \mu \mathrm{L}$ of each concentration were added to 96well plate and then $100 \mu \mathrm{L}$ of $135 \mathrm{U} / \mathrm{mL}$ mushroom tyrosinase in phosphate buffer solution (PBS, pH 6.8) were added. After pre-incubation at $25{ }^{\circ} \mathrm{C}$ for $10 \mathrm{~min}, 100 \mu \mathrm{L}$ of L-dopa $(0.5 \mathrm{mM}$, PBS $\mathrm{pH}$ 6.8) were added into 96-well plate. The reaction mixture was incubated for another $5 \mathrm{~min}$ at $25{ }^{\circ} \mathrm{C}$. The amount of dopachrome in the 
mixture was determined by the measurement of the absorbance of each well at $475 \mathrm{~nm}$. Kojic acid was used as positive control agent. The inhibitory percentage of tyrosinase was calculated according to the following equation: $\%$ inhibition $=\{[(A-B)$ - $(C-D)] /(A-B)\} \times 100(A:$ Ab at $475 \mathrm{~nm}$ without test substance; $B: \mathrm{Ab}$ at $475 \mathrm{~nm}$ without test substance and tyrosinase; $C$ : $\mathrm{Ab}$ at $475 \mathrm{~nm}$ with test substance; $D: \mathrm{Ab}$ at $475 \mathrm{~nm}$ with test substance, but without tyrosinase). All the tests were conducted in triplicate and $\mathrm{IC}_{50}$ was determined by interpolation of concentration $\%$ inhibition curve obtained by MSExcel based program.

\section{Supporting Information}

HR-ESI-MS, ${ }^{1} \mathrm{H}$ and ${ }^{13} \mathrm{C}$ NMR, COSY, HMBC and ROESY spectra for compounds $\mathbf{1}$ and 2.

\section{Acknowledgements}

The authors are grateful to MESRS, Algeria and French government for the Profas grant to Mr. Abbes Benmerache, to CNRS, Conseil Régional Champagne Ardenne, Conseil Général de la Marne, Ministry of Higher Education and Research (MESR), and to the PIANET CPER project for financial support.

\section{References}

Abedini, A., Roumy, V., Mahieux, S., Biabiany, M., Standaert-Vitse, A., Rivière, C., Sahpaz, S., Bailleul, F., Neut, C., Hennebelle, T., 2013. Rosmarinic acid and its methyl ester as antimicrobial components of the hydromethanolic extract of Hyptis atrorubens Poit. (Lamiaceae). J. Evid. Based Complementary Altern. Med. 604536

Ayoub, N., Al-Azizi, M., König, W., Kubeczka, K.H., 2006. Essentia oils and a novel polyacetylene from Eryngium yuccifolium Michaux. (Apiaceae). Flav.eur Frag. J. 21, 864-868.

Bendaikha, S., Gadaut, M., Harakat, D., Alabdul Magid, A., 2014. Acylated flavonol glycosides from the flower of Elaeagnus angustifolia L. Phytochemistry 103, 129-13.

Boutaghane, N., Voutquenne-Nazabadioko ,L., Harakat, D., Simon, A. Kabouche, Z., 2013. Triterpene saponins of Genista ulicina Spach. Phytochemistry 93, 176-181.

Celik, A., Aydinlik, N., Arslan, I., 2011. Phytochemical constituents and inhibitory activity towards Methicillin-resistant Staphylococcus aureus strains of Eryngium Species (Apiaceae). Chem Biodivers. 8, 454-459.

Bamm, J., Douira, A., 2002. Les Plantes Medicinales Dans La Foret De L'achach ( Plateau Central, Maroc ). Acta Bot. Malacit. 27, 131-145.

Erdem, S.A., Mitaine-Offer, A.C., Miyamoto, T., Kartal, M., LacailleDubois, M.A., 2015. Triterpene saponins from Eryngium kotschyi. Phytochemistry 110, 160-165.

Hiller, K., Otto, A., Gruendemann, E., 1980. Isolation of kaempferol-3$O$-(6- $O$ - $\beta$-D-glucopyranosyl)- $\beta$-D-galactopyranoside, a new flavonol glycoside from Eryngium planum L. Part 34: Knowledge of the constituents of some Saniculoideae. Pharmazie, 35, 113-114.

Kanchanapoom, T., Ruchirawa, S., 2007. Megastigmane glucoside from Asystasia gangetica (L.) T. Anderson. J. Nat. Med. 61, 430433.

Khalfallah, A., Berrehal, D., Kabouche, A., Karioti, A., Bilia, A.R., Kabouche, Z., 2014. Flavonoids, antioxidant and antibacterial activities of Eryngium triquetrum. Chem. Nat. Compd. 50, 130-132

Kuang, H.X., Zhang, Y.L., Li, G.Y., Min Zeng, W.M., Wang, H.R., Song, Q.Y., 2008. A new phenolic glycoside from the aerial parts of Dryopteris fragrans. Fitoterapia 79, 319-320.

Kupeli, E., Kartal, M., Aslan, S., Yesilada, E., 2006. Comparative evaluation of the anti-inflammatory and antinociceptive activity of Turkish Eryngium species. Ethnopharmacol. 107 , 32-37.

Le Claire, E., Schwaiger, S., Banaigs, B., Stuppner, H., Gafner, F., 2005. Distribution of a new rosmarinic acid derivative in Eryngium alpinum L. and other Apiaceae. J. Agric. Food Chem. 53, 4367-4372.
Merghache, D., Boucherit-Otmani, Z., Merghache, S., Chikhi, I., Selles, C., Boucherit, K., 2014. Chemical composition, antibacterial, antifungal and antioxidant activities of Algerian Eryngium tricuspidatum L. essential oil. Nat. Prod. Res. 28, 1-13.

Nacef, S., Ben Jannet, H., Hamza, M.A., Mighri, Z., 2008. Contribution to the phytochemical investigation of the plant Eryngium dichotomum Desf. (Apiaceae) from Tunisia. J. Soc.Chim. 10, 141-148.

Nawwar, M.A.M., El-Mousallamy, A.M.D., Barakat, H.H., 1989. Quercetin 3-glycosides from the leaves of Solanum nigrum. Phytochemistry 28, 1755-1757.

Ndip, R.N., Malange Tarkang, A.E., Mbullah, S.M., Luma, H.N, Malongue, A., Ndi, L.M., Nyongbela, K., Wirmum, K., Efange, S.M., 2007. In vitro anti-helicobacter pylori activity of extracts of selected medicinal plants from North West Cameroon. J. Ethnopharmacol. 114, 452-457.

Quezel P, Santa S., 1963. Nouvelle Flore de l'Algérie et des régions désertiques méridionales, vol. 1-2. CNRS, Paris.

Suciu, S., Pârvu, A.E., 2012). Comparative study on the effects of Eryngium sp. Extracts in an acute inflammation model in rat. Annals of RSCB.17, 86-91.

Tahri, N., Zidane, L., El Yacoubi, H., Fadli, M., Rochdi, A., llal Douira, A., 2011. Contribution à l'étude de la biodiversité de la région de Ben Slimane (Ouest marocain): Catalogue floristique des plantes vasculaires. J. Anim. Plant Sci. 12, 1632-1652.

Tanja, G., Maki, K., Herbert, K.A., 2005. Phenol glucoside, uncommon coumarins and flavonoids from Pelargonium sidoides DC, Z. Naturforsch C. 60, 677-682.

Venditti, A., Bianco, A., Tomassini, L., Nicoletti M., 2014. A Cmethylated resacetophenone from Cistus monspeliensis L. Fitoterapia 95, 182-185.

Wen, Q., Lin, X., Liu, Y., Xu, X., Liang, T., Zheng, N., Kintoko, K., Huang, R., 2012. Phenolic and lignan glycosides from the butanol extract of Averrhoa carambola L. Root. Molecules 17,12330-12340

Yang, Z., Li-Jun, Y., Kun, J., Chang-Heng, T., Jun-Jie, T., Pei-Ming, Y., Da-Yuan, Z., 2012. Glycosidic constituents from the roots and rhizomes of Melicope pteleifolia. Carbohydr. Res. 361, $114-119$

Yasuhiro, S., Yoshihisa ,T., Gisho, H., Michiho, I., Yoshio, T., Olimjon, K.K., Ozodbek, A, 2001. Terpenoids and $\gamma$-pyrone derivatives from Prangos tschimganica. Phytochemistry 57, 135-141.

Yurdakok, B., Baydan, E., 2013. Cytotoxic effects of Eryngium kotschyi and Eryngium maritimum on Hep2, HepG2, Vero and U138 MG cell lines. Pharm. Biol.51, 1579-1585. 